\title{
Monika KORDOWSKA
}

Uniwersytet Warszawski

Sylwia KULCZYK

Uniwersytet Warszawski

\section{NATURA DLA MIESZCZUCHA - ROLA MIEJSKICH MUZEÓW PRZYRODNICZYCH W POPULARYZACJI I EDUKACJI PRZYRODNICZEJ}

\section{Wstęp}

Wizyty w muzeach są jedną z podstawowych form aktywności krajoznawczej. Placówki te nie tylko są miejscem gromadzenia i przechowywania zbiorów, ale mają też istotny wpływ na kształtowanie świadomości i postaw społecznych. Kulturotwórcza rola muzeów nie odnosi się wyłącznie do aspektów historycznych czy artystycznych. Obejmuje ona również kształtowanie relacji człowieka z przyrodą. Wydaje się, że ta ostatnia funkcja ma szczególne znaczenie współcześnie, kiedy powszechnie obserwuje się rozluźnienie więzów łączących ludzi z naturą. Zjawisko to jest ściśle związane z postępującą urbanizacją (Balmford i in., 2009) i obejmuje coraz większą część społeczeństwa. Jak podaje Organizacja Narodów Zjednoczonych, już 74\% Europejczyków mieszka w miastach (United Nations, 2018). Poza negatywnym wpływem na zdrowie (Abraham, Sommerhalder, Abel, 2010) brak kontaktu z przyrodą grozi utratą zdobywanej przez pokolenia wiedzy o gospodarczym i kulturowym znaczeniu poszczególnych elementów przyrodniczych, straceniem umiejętności odpowiedzialnego korzystania z dóbr przyrody oraz brakiem świadomości kluczowej roli elementów przyrodniczych w życiu na Ziemi. Z tego względu opisywane zjawisko uważane jest za istotne zagrożenie cywilizacyjne (Soga, Gaston, 2016).

Celem niniejszego artykułu jest charakterystyka polskich muzeów przyrodniczych znajdujących się w miastach, a w szczególności odpowiedź na pytanie, czy i w jaki sposób placówki te przyczyniają się do zachowania bądź odbudowania powiązań między człowiekiem a środowiskiem 
przyrodniczym. Podstawą wyodrębnienia muzeów przyrodniczych spośród wszystkich tego typu placówek w kraju były: publikacja książkowa 1000 muzeów w Polsce. Przewodnik (Folga-Januszewska, 2011), dane pozyskane z Narodowego Instytutu Muzealnictwa i Ochrony Zbiorów (2019) oraz wykaz Ministerstwa Kultury i Dziedzictwa Narodowego (2019). Szczegółowe informacje dotyczące poszczególnych obiektów pozyskano ze stron internetowych zidentyfikowanych obiektów w październiku 2019 r. W wybranych miejscach autorki były osobiście i zgromadziły na ich temat dokumentację opisową i fotograficzną.

\section{Muzeum przyrodnicze zamiast przyrody?}

Muzeum, definiowane przez Międzynarodową Radę Muzeów jako „trwale istniejąca instytucja, która nie jest nastawiona na osiągnięcie zysku, służąca społeczeństwu i jego rozwojowi, otwarta dla publiczności, która pozyskuje, konserwuje, udostępnia i wystawia w celu badawczym, edukacyjnym lub dla rozrywki materialne i niematerialne świadectwa ludzi oraz ich środowiska" (Kodeks Etyki ICOM dla Muzeów, 2018, s. 2), powszechnie uważane jest za potencjalną atrakcję turystyczna, a jednocześnie miejsce o dużym znaczeniu edukacyjnym. Jak podkreślają Stasiak i Włodarczyk (2013), warunkiem efektywnego pełnienia tej funkcji jest sposób komunikowania się z odbiorcami. Charakter współczesnego społeczeństwa wymusza zmianę profilu muzeum z informacyjnego na performatywny. Muzeum powinno być zatem placówką interaktywna, angażującą odwiedzających - wciągającą ich do dialogu, pobudzającą do dociekań, zadawania pytań oraz samodzielnego poszukiwania odpowiedzi (Stasiak, 2006). Stasiak zauważa również, że muzeum należy traktować jednocześnie jako obiekt będący indywidualnym produktem turystycznym i jako część większej całości, z którą wiąże je specyfika miejsca (np. historia budynku, w którym ulokowane są zbiory), wydarzenia (wizyty w muzeum często towarzyszą np. konferencjom), szlaku (ekspozycja muzealna może być elementem zaplanowanej trasy turystycznej) oraz imprezy (składowa pakietu usług turystycznych) (Stasiak, 2000).

Początków polskiego muzealnictwa upatruje się w powstałych w XVI i XVII w. kolekcjach władców i magnatów (Jędrysiak, 2009). Oprócz dzieł sztuki i książek zbiory te obejmowały również okazy przyrodnicze, przede wszystkim zwierzęta lub ich części oraz minerały. W XIX w. w Promnicach na miejscu starego dworku Promnitzów wzniesiono Zameczek Myśliwski, w którym prezentowano trofea myśliwskie w postaci poroży 
jeleni, gromadzono tam także martwe zwierzęta, które odpowiednio spreparowane zdobiły wnętrza pomieszczeń (Kluss, Kruczek, 2010). Z kolei w tzw. zamku w Kórniku T. Działyński zebrał sporą kolekcję minerałów (1874 r.) - miała ona być zaczątkiem projektowanego przez J. Działyńskiego muzeum historii naturalnej (Kąsinowska, 1998).

Na stronie internetowej Głównego Urzędu Statystycznego (2019) wyjaśniono pojęcie muzeum przyrodniczego bardzo lapidarnie, opisując je jako obiekt, w którym gromadzone są okazy przyrody. Znacznie bardziej rozbudowaną definicję przedstawiła Kordowska (2015, s. 26), według której:

muzeum przyrodnicze to instytucja, która pozyskuje, konserwuje i udostępnia zbiory, złożone z żywych lub martwych okazów przyrody, może prowadzić badania naukowe $\mathrm{z}$ dziedziny nauk przyrodniczych; ponadto przekazuje wiedzę o zebranych zbiorach w sposób przystępny dla zwiedzających w postaci działań edukacyjnych, ale także edukacji $\mathrm{w}$ formie rozrywki.

Jak wynika z tego zapisu, bezpośrednia łączność z natura, realizowana choćby poprzez ulokowanie zbiorów in situ na terenie cennym przyrodniczo, nie jest immanentną cechą zbiorów przyrodniczych. Co więcej, placówki muzealne (czy - w skromniejszej wersji - ośrodki edukacji ekologicznej), zlokalizowane np. w parkach narodowych, mają znacznie krótszą historię aniżeli kolekcje przyrodnicze przywożone z całego świata do znaczących ośrodków miejskich (np. Museum of Natural History w Londynie). W 2015 r. M. Kordowska zidentyfikowała w Polsce 83 muzea przyrodnicze. Więcej niż połowa z nich jest oddalona o ponad godzinę drogi samochodem od obszarów cennych przyrodniczo. Specyfikę omawianych placówek, sprowadzającą się do konieczności atrakcyjnego zaprezentowania przyrody niejako nieobecnej w danym miejscu, dostrzegli też Lijewski, Mikułowski i Wyrzykowski (2008), którzy w swojej klasyfikacji walorów turystycznych Polski muzea przyrodnicze umieścili w kategorii „walorów przyrodniczych utworzonych przez człowieka”.

\section{Specyfika miejskich muzeów przyrodniczych}

\subsection{Lokalizacja}

Autorki artykułu ustaliły, że 30 placówek muzealnych o charakterze przyrodniczym znajduje się w miastach powyżej 100 tys. mieszkańców. Obiekty te są położone poza obszarami bogatymi w walory przyrodnicze, 
także w dużych aglomeracjach miejskich, np. w Warszawie, Wrocławiu czy Krakowie (rys. 1). Muzea przyrodnicze rozmieszczone są w miastach na terenie całego kraju. Największa ich liczba znajduje się w województwie małopolskim i mazowieckim - po sześć obiektów w Krakowie i Warszawie. W większości pozostałych miast znajduje się od jednego do dwóch obiektów muzealnych. W województwach kujawsko-pomorskim, lubuskim i podkarpackim w miastach powyżej 100 tys. mieszkańców nie ma żadnych muzeów przyrodniczych (rys. 1).

Miejskie muzea przyrodnicze są zazwyczaj położone w znacznej odległości od atrakcji przyrodniczych. $Z$ tego powodu może być trudno przyciągnąć $\mathrm{w}$ takie miejsca zwiedzających szczególnie zainteresowanych przyrodą. O ich popularności decyduje nie tylko wartość zgromadzo-

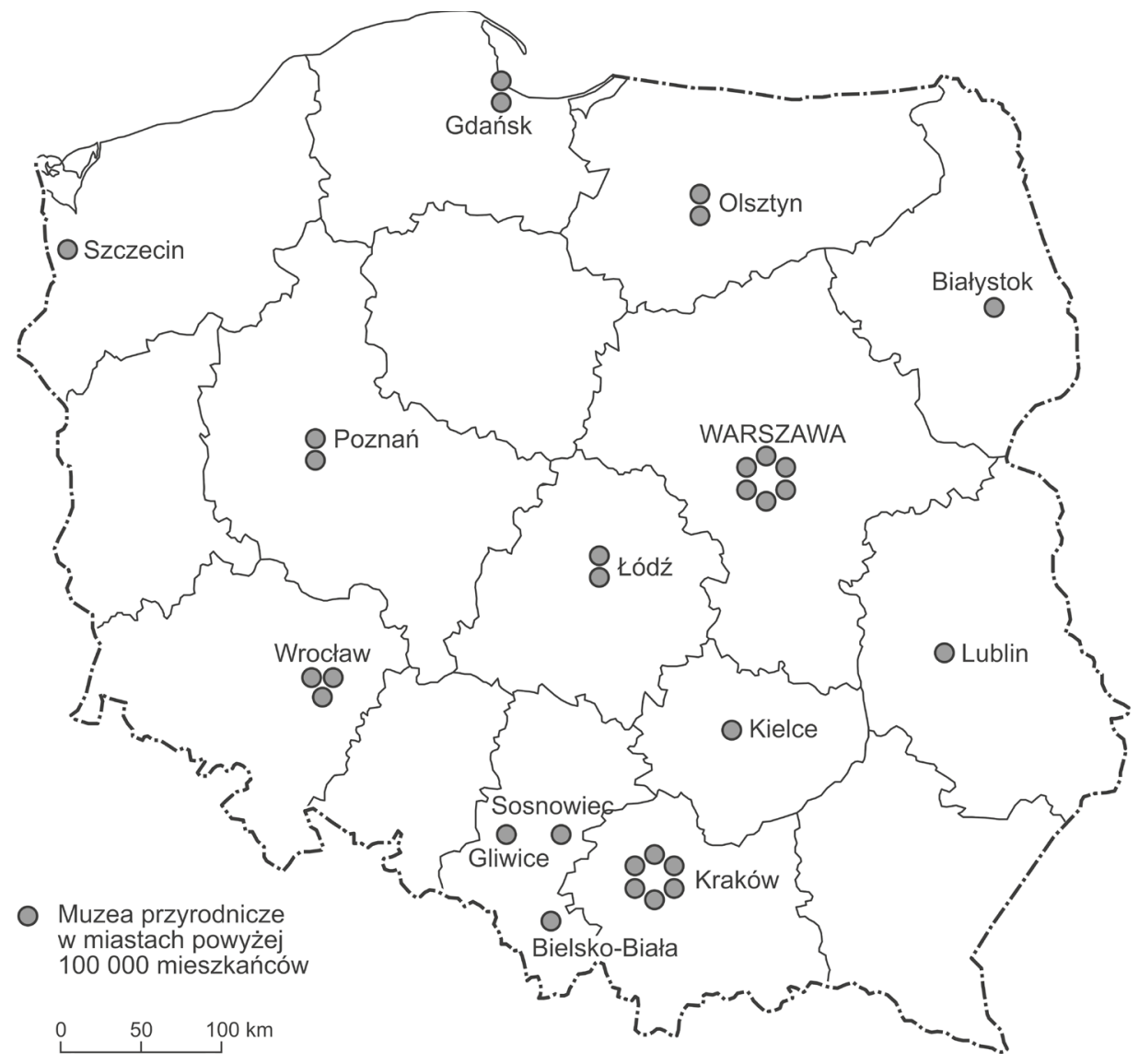

Rysunek 1. Rozmieszczenie muzeów przyrodniczych w polskich miastach Źródło: opracowanie własne 
nych zbiorów, ale również efektywna promocja i kreowanie pozytywnego wizerunku (Stasiak, 2007). Często muzea te różnią się od obiektów umiejscowionych na obszarach cennych przyrodniczo pod względem funkcji edukacyjnej i rozrywkowej. Specyficzna jest również ich lokalizacja w samym mieście. Siedzibami tego typu muzeów są zazwyczaj budynki uczelni lub innych państwowych instytucji naukowych, np. Polskiej Akademii Nauk lub Państwowego Instytutu Geologicznego - jednostki te są także odpowiedzialne za zarządzanie takimi muzeami.

\subsection{Rodzaje kolekcji przyrodniczych}

Zidentyfikowane muzea przyrodnicze różnią się między sobą przede wszystkim rodzajami kolekcji przyrodniczych, ich wielkością, oryginalnością oraz sposobami prezentacji. W muzeach wyróżniono pięć typów kolekcji przyrodniczych, obejmujących okazy: fauny, flory, bursztynu oraz geologiczne i paleontologiczne. Na rys. 2 zaprezentowano popularność poszczególnych grup.

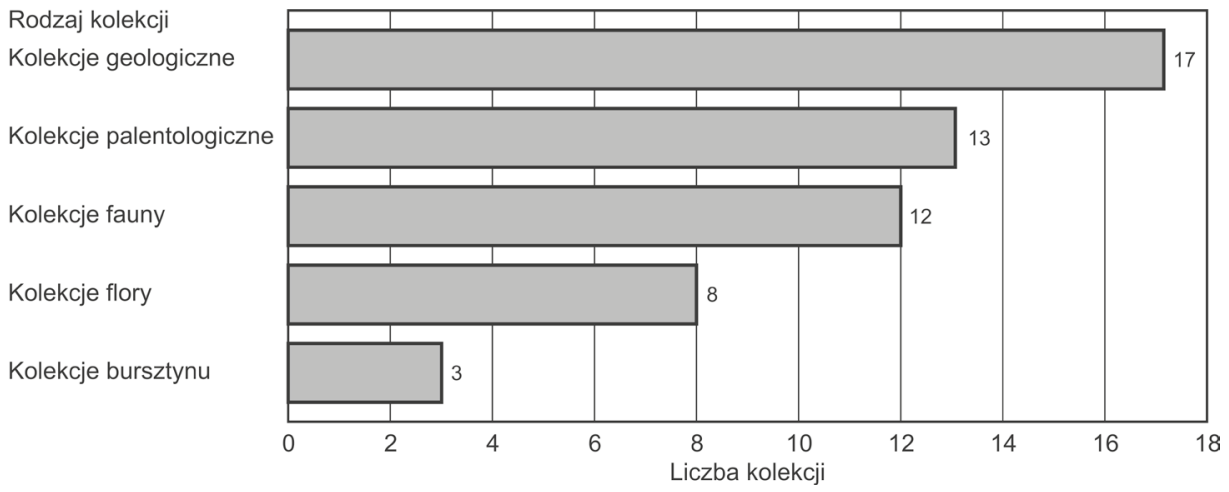

Rysunek 2. Popularność rodzajów kolekcji przyrodniczych $\mathrm{w}$ miejskich muzeach przyrodniczych Źródło: opracowanie własne

Najczęściej spotykanym rodzajem kolekcji przyrodniczych są zbiory okazów geologicznych (minerałów, skał i złóż), prezentowane w różnych formach. Małe okazy są umieszczane w gablotach zarówno otwartych, jak i całkowicie oszklonych. Z kolei duże skały rozmieszcza się w salach wystawowych bez dodatkowych zabezpieczeń, a także na świeżym powietrzu w tzw. lapidariach (fot. 1). Podczas zajęć edukacyjnych odwiedzający mogą dotykać wybranych do tego celu okazów. 


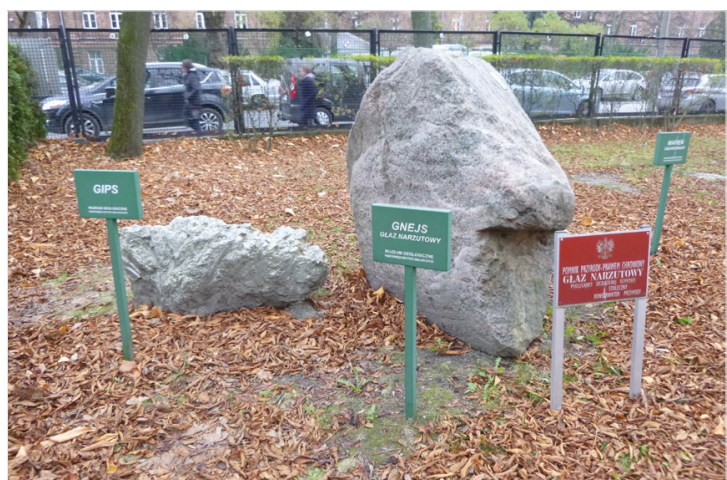

Fotografia 1. Lapidarium obok Muzeum Geologicznego Państwowego Instytutu Geologicznego w Warszawie Źródło: M. Kordowska (listopad 2019)

Druga, równie liczna, grupę kolekcji stanowią wystawy, na których są prezentowane zbiory paleontologiczne, w głównej mierze skamieniałości przewodnie różnych epok, tj. zachowane w skałach fragmenty kości i szczątki roślin. W tych kolekcjach szczególną popularnością cieszą się wystawy związane z dinozaurami i zwierzętami prehistorycznymi, a zwłaszcza ich szkielety. Pokaźne okazy można zobaczyć m.in. w Muzeum Geologicznym Państwowego Instytutu Geologicznego w Warszawie (fot. 2). Tego typu obiekty są szczególnie atrakcyjne dla dzieci.

Popularne są również kolekcje fauny, najliczniej występujące w muzeach zoologicznych i przyrodniczych. Obejmują zbiory okazów fauny,

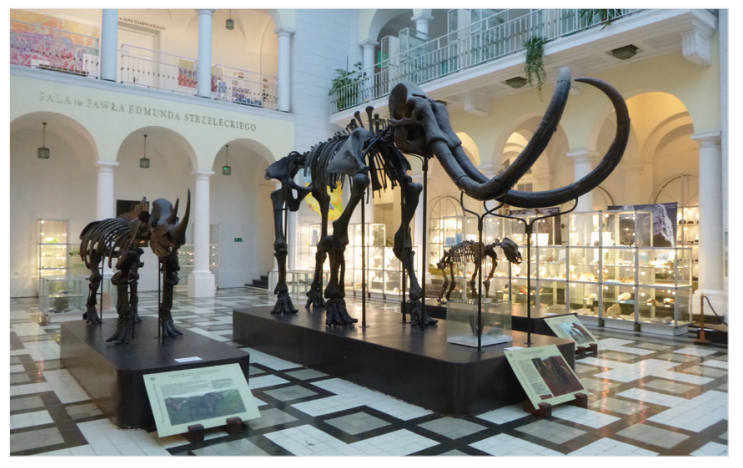

Fotografia 2. Szkielet nosorożca i mamuta włochatego w Muzeum Geologicznym

Państwowego Instytutu Geologicznego w Warszawie Źródło: M. Kordowska (listopad 2019) 
czyli preparowane zwierzęta lub ich części, takie jak: kości, skorupki, pióra, rogi lub poroża, a także kolekcje bezkręgowców. Często są prezentowane $\mathrm{w}$ postaci dioram, na których zwierzęta zostały pokazane w ich naturalnym środowisku (fot. 3, 4). Takie wystawy mają duże znaczenie w miastach, gdzie nie ma bezpośredniego kontaktu z przyrodą. Kolekcje te nie są one jednak tak bogate, jak w muzeach przyrodniczych zlokalizowanych na obszarach cennych przyrodniczo lub w ich pobliżu (Kordowska, 2015).
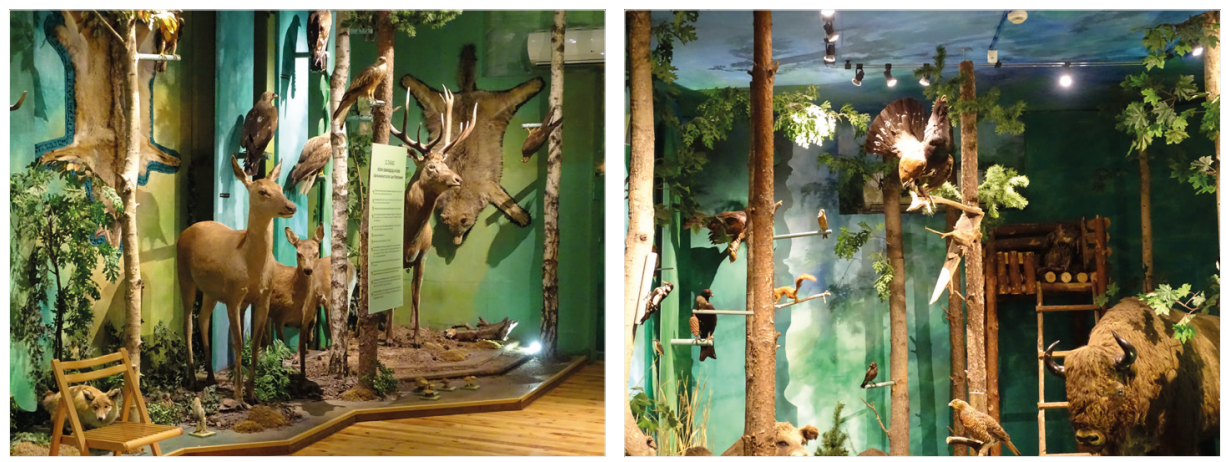

Fotografia 3, 4. Dioramy, na których zaprezentowano kolekcje fauny w Muzeum Łowiectwa i Jeździectwa w Warszawie Źródło: M. Kordowska (wrzesień 2019)

Mniej jest kolekcji flory. Obejmują one przede wszystkim okazy gatunków rodzimych, które prezentowane są najczęściej w szklanych gablotach lub w zielnikach. Ponadto rośliny i ich zbiorowiska są przedstawiane na planszach w formie barwnych fotografii i opisów. Kolekcje takie są znacznie mniejsze pod względem liczby okazów niż zbiory fauny.

Z kolei ekspozycje bursztynu są zaledwie trzy. Największa z nich znajduje się w Muzeum Bursztynu w Gdańsku. Na wystawach są zaprezentowane: historia powstania bursztynu, jego właściwości, sposoby pozyskiwania oraz obróbka na przestrzeni dziejów (Muzeum Gdańska, 2019).

W miejskich muzeach przyrodniczych $\mathrm{w}$ jednym obiekcie muzealnym jednocześnie prezentowane są różne kolekcje. Najbardziej zróżnicowane pod tym względem są muzea nazywane przyrodniczymi i centra edukacji przyrodniczej. W muzeach geologicznych najczęściej prezentowane są wyłącznie kolekcje geologiczne, a w muzeach paleontologicznych zbiory paleontologiczne. 


\subsection{Sposoby prezentacji kolekcji przyrodniczych}

Kolekcje przyrodnicze są prezentowane na różne sposoby. Ze względu na formy przedstawienia eksponatów można wyróżnić muzea tradycyjne, interaktywne i wirtualne (Kordowska, 2015; Stefanik, Kamel, 2013). Muzea tradycyjne usytuowane są w konkretnym budynku, a eksponaty umieszcza się najczęściej w szklanych gablotach. W muzeach interaktywnych, obok eksponatów prezentowanych w sposób tradycyjny, pojawiają się pomoce multimedialne, np. infokioski lub nagrania dźwiękowe i wideo. W niektórych instytucjach kolekcje udostępniane są dodatkowo za pomocą Internetu, w postaci tzw. wirtualnych spacerów.

Zbiory w muzeach przyrodniczych w miastach swoje eksponowane są w głównej mierze w sposób tradycyjny (rys. 3). Okazy, w postaci preparowanych zwierząt lub ich części, znajdują się w szklanych gablotach. W ten sposób prezentuje się również okazy geologiczne (fot. 5) i paleontologiczne. Ich uzupełnieniem są fotografie, plansze i modele oraz opisy i wyjaśnienia. Okazy roślinne mogą być zgromadzone i prezentowane $\mathrm{w}$ formie zielników, np. w Ogrodzie Botanicznym Uniwersytetu Jagiellońskiego.

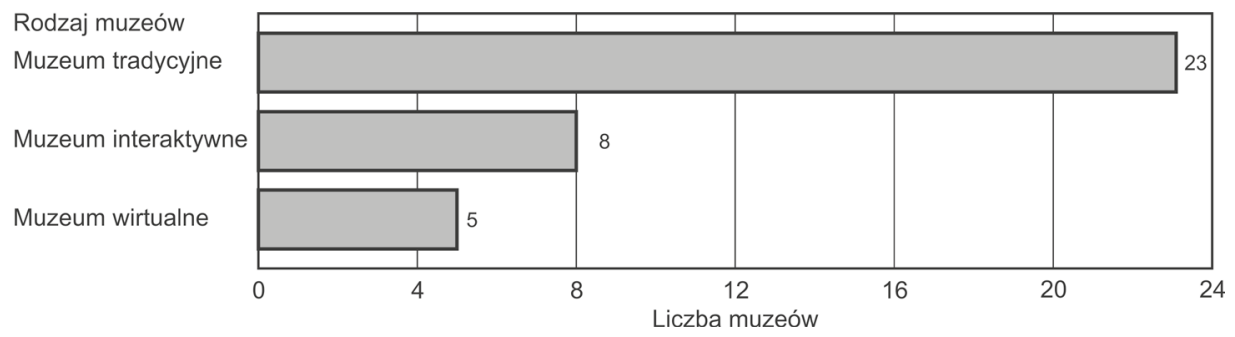

Rysunek 3. Sposoby prezentacji zbiorów w miejskich muzeach przyrodniczych Źródło: opracowanie własne

Znacznie mniej jest muzeów interaktywnych (rys. 3), czyli takich, w których tradycyjne wystawy są wzbogacone o elementy multimedialne. Infokioski znajdują się m.in. w Muzeum Przyrodniczym Uniwersytetu Łódzkiego w Łodzi, a także w Uniwersyteckim Centrum Przyrodniczym im. prof. Andrzeja Myrchy w Białymstoku. Z kolei w Muzeum Ewolucji Instytutu Paleobiologii Polskiej Akademii Nauk w Warszawie można posłuchać odgłosów wymarłych gadów (fot. 6).

Najmniej liczne są muzea wirtualne. W przypadku muzeów przyrodniczych w mieście są to wyłącznie formy uzupełniające tradycyjne 


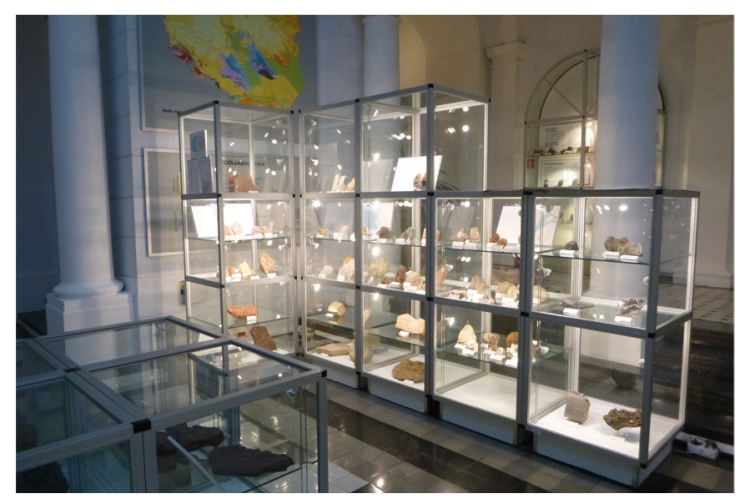

Fotografia 5. Okazy geologiczne w Muzeum Geologicznym

Państwowego Instytutu Geologicznego w Warszawie Źródło: M. Kordowska (listopad 2019)

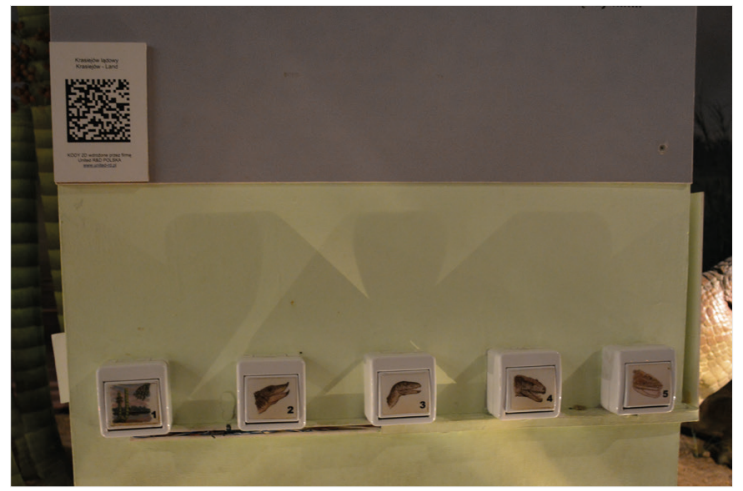

Fotografia 6. Przyciski dźwiękowe w Muzeum Ewolucji Instytutu Paleobiologii

Polskiej Akademii Nauk w Warszawie Źródło: M. Kordowska (wrzesień 2014)

obiekty. Kolekcje prezentowane są w postaci wirtualnego spaceru. Najbardziej rozbudowaną wersją muzeum wirtualnego jest Muzeum Przyrodnicze Instytutu Systematyki i Ewolucji Zwierząt Polskiej Akademii Nauk w Krakowie (fot. 7). Oprócz tradycyjnego wirtualnego spaceru na zwiedzających czekają puzzle i kreator pocztówek. Strona zawiera także zakładkę "Warto zobaczyć" - są tam prezentowane zabytki Krakowa położone blisko Muzeum (Instytut Systematyki i Ewolucji Zwierząt Polskiej Akademii Nauk, 2019). 


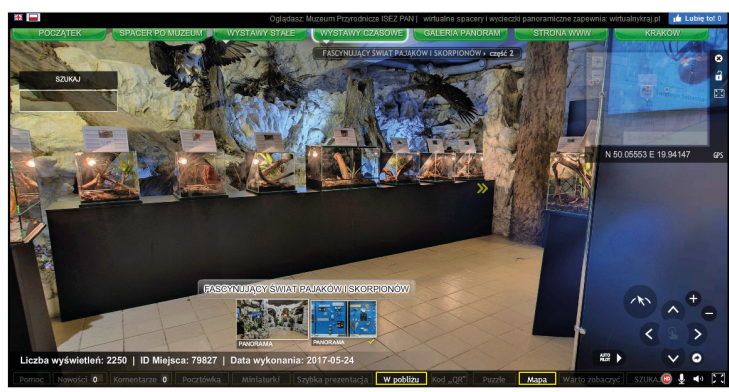

Fotografia 7. Wirtualny spacer po Muzeum Przyrodniczym Instytutu Systematyki i Ewolucji Zwierząt Polskiej Akademii Nauk w Krakowie Źródło: Instytut Systematyki i Ewolucji Zwierząt Polskiej Akademii Nauk (2019)

\section{Formy działalności miejskich muzeów przyrodniczych}

Najważniejsze funkcje muzeów przyrodniczych w miastach, oprócz działalności naukowo-badawczej, to: edukacja i upowszechnianie wiedzy o środowisku przyrodniczym dla mieszkańców miast i turystów oraz rozrywka i rekreacja.

\subsection{Funkcja edukacyjna miejskich muzeów przyrodniczych}

Najlepiej rozbudowaną funkcją tego typu obiektów w mieście jest działalność edukacyjna. Ma ona bardzo zbliżony charakter do inicjatyw podejmowanych w muzeach przyrodniczych zlokalizowanych na obszarach cennych przyrodniczo lub w ich pobliżu (Kordowska, 2015). Muzea położone $\mathrm{w}$ miastach cechuje jednak różnorodność form proponowanej działalności edukacyjnej (tab. 1). Oferta kierowana do grup zorganizowanych różni się od przygotowanej z myślą o osobach indywidualnych.

Najprostszą formą działalności edukacyjnej dla grup zorganizowanych jest zwiedzanie muzeum z przewodnikiem (tab. 1). Dzięki temu można zobaczyć nie tylko wszystkie warte obejrzenia miejsca, lecz również dowiedzieć się wielu interesujących rzeczy. Ponadto przewodnicy często lepiej niż nauczyciele potrafią podczas oglądania wystaw wzbudzić zainteresowanie dzieci i młodzieży, zadając różnego rodzaju pytania, zagadki, a niekiedy nawet przeprowadzając konkursy. Uzupełnieniem i urozmaiceniem ekspozycji stałych są wystawy czasowe, na których 
mogą być prezentowane obiekty tego samego rodzaju co inne eksponaty w muzeum, lub wystawy fotografii, malarstwa lub rzeźby.

Inną popularną formą edukacyjną są lekcje muzealne (tab. 1). Ich charakter, czas trwania i zakres przekazywanych informacji są dostosowane do wieku zwiedzających (przedszkolaków, uczniów szkół podstawowych, gimnazjalnych, ponadgimnazjalnych, studentów). Lekcje muzealne mogą być uzupełnione o prezentacje multimedialne lub wyświetlenie filmu przyrodniczego. Co więcej, dla urozmaicenia zajęć wprowadza się karty pracy, np. w Muzeum Przyrodniczym im. prof. Władysława Rydzewskiego we Wrocławiu (Muzeum Przyrodnicze Uniwersytetu Wrocławskiego, 2019).

Tabela 1. Formy działalności edukacyjnej dla grup zorganizowanych - zajęcia stacjonarne

\begin{tabular}{|l|l|}
\hline \multicolumn{1}{|c|}{ Działalność edukacyjna stacjonarna } & \multicolumn{1}{|c|}{ Przykład muzeum przyrodniczego } \\
\hline $\begin{array}{l}\text { Zwiedzanie muzeum z przewodnikiem } \\
\text { dla starszych grup przedszkolaków, ucz- } \\
\text { niów szkół podstawowych, gimnazjów, } \\
\text { liceów ogólnokształcących oraz innych } \\
\text { szkół średnich }\end{array}$ & $\begin{array}{l}\text { Muzeum Geologiczne Państwowego In- } \\
\text { stytutu Geologicznego w Warszawie; Mu- } \\
\text { zeum Geologiczne Uniwersytetu Szcze- } \\
\text { cińskiego w Szczecinie; Muzeum Przyro- } \\
\text { dy w Olsztynie }\end{array}$ \\
\hline $\begin{array}{l}\text { Lekcje muzealne z pracownikami muze- } \\
\text { um dla starszych grup przedszkolaków, }\end{array}$ & $\begin{array}{l}\text { Muzeum Bursztynu w Gdańsku; Muze- } \\
\text { um Przyrodnicze im. prof. Władysława }\end{array}$ \\
$\begin{array}{l}\text { uczniów szkół podstawowych, gimnazjów, } \\
\text { liceów ogólnokształcacych oraz innych } \\
\text { szkół średnich }\end{array}$ & $\begin{array}{l}\text { Zoologiczne Uniwersytetu Marii Curie- } \\
\text {-Skłodowskiej w Lublinie }\end{array}$ \\
\hline $\begin{array}{l}\text { Lekcje muzealne z nauczycielem na posta- } \\
\text { wie przygotowanych przez muzeum scena- } \\
\text { riuszy zajęć dla starszych grup przedszko- } \\
\text { laków, uczniów szkół podstawowych, gim- } \\
\text { nazjów, liceów ogólnokształcacych oraz } \\
\text { innych szkół średnich }\end{array}$ & $\begin{array}{l}\text { Uniwersyteckie Centrum Przyrodnicze } \\
\text { im. prof. Andrzeja Myrchy w Białymstoku }\end{array}$ \\
\hline $\begin{array}{l}\text { Warsztaty przyrodnicze dla starszych grup } \\
\text { przedszkolnych, uczniów szkół podstawo- } \\
\text { wych, gimnazjów, liceów ogólnokształcą- } \\
\text { cych oraz innych szkół średnich }\end{array}$ & $\begin{array}{l}\text { Muzeum Geologiczne Uniwersytetu } \\
\text { Szczecińskiego w Szczecinie; Muzeum } \\
\text { Ewolucji Instytutu Paleobiologii Polskiej } \\
\text { Akademii Nauk w Warszawie; Pracow- } \\
\text { nia Muzeum Ziemi w Poznaniu }\end{array}$ \\
\hline $\begin{array}{l}\text { Muzeum Ewolucji Instytutu Paleobiolo- } \\
\text { Wystawy czasowe }\end{array}$ & $\begin{array}{l}\text { Mii Polskiej Akademii Nauk w Warsza- } \\
\text { wie; Muzeum Paleobotaniczne Insty- } \\
\text { tutu Botaniki Polskiej Akademii Nauk } \\
\text { w Krakowie; Uniwersyteckie Centrum } \\
\text { Przyrodnicze im. prof. Andrzeja Myrchy } \\
\text { w Białymstoku }\end{array}$ \\
\hline
\end{tabular}


Tabela 1 (cd.)

\begin{tabular}{|c|l|}
\hline Działalność edukacyjna stacjonarna & \multicolumn{1}{|c|}{ Przykład muzeum przyrodniczego } \\
\hline Zajęcia dydaktyczne dla studentów & $\begin{array}{l}\text { Centrum Edukacji Przyrodniczej Uni- } \\
\text { wersytetu Jagiellońskiego w Krakowie; } \\
\text { Muzeum Geologii Złóż im. Czesława Po- } \\
\text { borskiego w Gliwicach; Muzeum Geolo- } \\
\text { giczne im. Jana Ziomka w Łodzi }\end{array}$ \\
\hline
\end{tabular}

Źródło: opracowanie własne na podstawie informacji zawartych na stronach internetowych miejskich muzeów przyrodniczych.

W muzeach przyrodniczych $\mathrm{w}$ miastach organizowane są także dostosowane do wieku zwiedzających warsztaty edukacyjne o zróżnicowanej tematyce. Mogą dotyczyć gatunków roślin, zwierząt, ich siedlisk, a także osobliwości geologicznych i paleontologicznych. Polegają m.in. na rozpoznawaniu i preparowaniu skamieniałości, oglądaniu obiektów pod mikroskopem lub wykonywaniu prostych doświadczeń (fot. 8, 9).
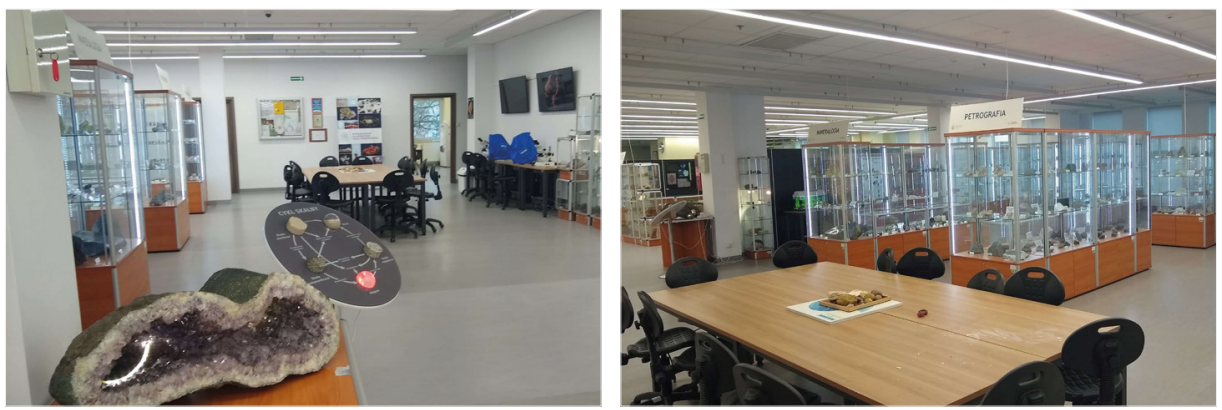

Fotografia 8, 9. Część sali muzealnej wydzielona na warsztaty edukacyjne w Muzeum Geologicznym Uniwersytetu Szczecińskiego w Szczecinie Źródło: M. Kupiec (listopad 2019)

W odróżnieniu od lekcji i warsztatów edukacyjnych w muzeach zlokalizowanych na obszarach cennych przyrodniczo lub w ich pobliżu w instytucjach miejskich tego typu działalność edukacyjna odbywa się w głównej mierze w budynkach. Działalność edukacyjna w terenie należy do rzadkości. Najbardziej popularną formą jest zwiedzanie ekspozycji na otwartej przestrzeni (tab. 2), np. lapidariów w muzach geologicznych.

Najczęściej terenowe warsztaty przyrodnicze prowadzone są podczas różnego rodzaju imprez ogólnopolskich, np. Nocy Muzeów. Z kolei 
spośród wszystkich muzeów przyrodniczych w miastach najbardziej rozwiniętą edukację terenową oferuje Muzeum Nauk o Ziemi Uniwersytetu Śląskiego w Sosnowcu, w którym organizowane są warsztaty pt. „Geologia w terenie”. W trakcie tych spotkań uczniowie pracują z mapą topograficzną i kompasem, a także uczą się przeprowadzać analizę odkrywki geologicznej oraz rozpoznawać skamieniałości (Muzeum Nauk o Ziemi Uniwersytetu Śląskiego, 2019).

Tabela 2. Formy działalności edukacyjnej dla grup zorganizowanych i osób indywidualnych - zajęcia terenowe

\begin{tabular}{|l|l|}
\hline $\begin{array}{c}\text { Działalność edukacyjna } \\
\text { terenowa }\end{array}$ & \multicolumn{1}{c|}{ Przykład muzeum przyrodniczego } \\
\hline $\begin{array}{l}\text { Zwiedzanie ekspozycji } \\
\text { na otwartej przestrzeni } \\
\text { (grupy zorganizowane, } \\
\text { osoby indywidualne) }\end{array}$ & $\begin{array}{l}\text { Uniwersyteckie Centrum Przyrodnicze im. prof. Andrzeja } \\
\text { Myrchy w Białymstoku; Muzeum Geologiczne w Kielcach; } \\
\text { Muzeum Nauk o Ziemi Uniwersytetu Śląskiego w Sosnowcu }\end{array}$ \\
\hline $\begin{array}{l}\text { Warsztatyprzyrodnicze } \\
\text { w terenie(osoby indywi- } \\
\text { dualne) }\end{array}$ & $\begin{array}{l}\text { Muzeum Łowiectwa i Jeździectwa w Warszawie; Uniwer- } \\
\text { syteckie Centrum Przyrodnicze im. prof. Andrzeja Myrchy } \\
\text { w Białymstoku; Muzeum Przyrody w Olsztynie }\end{array}$ \\
\hline
\end{tabular}

Źródło: opracowanie własne na podstawie informacji zawartych na stronach internetowych miejskich muzeów przyrodniczych.

Działalność edukacyjna dla osób indywidualnych obejmuje te same formy co dla grup zorganizowanych. Jednak przebieg zajęć jest często dostosowany do grup zróżnicowanych wiekowo, m.in. rodzin z dziećmi, dzieci, a także samych dorosłych (tab. 3).

Indywidualni zwiedzający, podobnie jak grupy zorganizowane, mogą skorzystać z usług przewodnika. Jednak nie w każdym muzeum oferowane jest takie rozwiązanie. $W$ niektórych instytucjach pojawiły się audioprzewodniki, czyli nieduże urządzenia elektroniczne wyposażone w słuchawki, z nagraniami, na których opisano szczególnie ciekawe eksponaty. Zwiedzanie z wykorzystaniem audioprzewodnika oferowane jest w Muzeum Przyrodniczym Uniwersytetu Łódzkiego w Łodzi (Muzeum Przyrodnicze Uniwersytetu Łódzkiego, 2019).

Warsztaty przyrodnicze dla osób indywidualnych organizowane są najczęściej podczas ogólnopolskich imprez oraz różnych świąt, np. Dnia Dziecka lub dni wolnych (wakacji, ferii zimowych). Mają one podobny charakter jak warsztaty dla grup zorganizowanych, jednak większy nacisk kładziony jest na aspekty praktyczne. Najczęściej oferowane 
Tabela 3. Formy działalności edukacyjnej dla indywidualnych zwiedzających

\begin{tabular}{|l|l|}
\hline \multicolumn{1}{|c|}{$\begin{array}{c}\text { Działalność } \\
\text { edukacyjna stacjonarna }\end{array}$} & \multicolumn{1}{c|}{ Przykład muzeum przyrodniczego } \\
\hline $\begin{array}{l}\text { Zwiedzanie muzeum } \\
\text { z przewodnikiem dla osób } \\
\text { indywidualnych } \\
\text { (także z audioprzewodnikiem) }\end{array}$ & $\begin{array}{l}\text { Muzeum Inkluzji w Bursztynie w Gdańsku; Mu- } \\
\text { zeum Przyrodnicze Instytutu Systematyki i Ewo- } \\
\text { lucji Zwierząt Polskiej Akademii Nauk w Krakowie; } \\
\text { Muzeum Przyrody w Olsztynie }\end{array}$ \\
\hline $\begin{array}{l}\text { Warsztaty edukacyjne } \\
\text { dla różnych grup wiekowych }\end{array}$ & $\begin{array}{l}\text { Muzeum Ewolucji Instytutu Paleobiologii Polskiej } \\
\text { Akademii Nauk w Warszawie; Muzeum Geologicz- } \\
\text { ne Uniwersytetu Szczecińskiego w Szczecinie; Pra- } \\
\text { cownia Muzeum Ziemi w Poznaniu }\end{array}$ \\
\hline Konkursy przyrodnicze & $\begin{array}{l}\text { Muzeum Geologiczne w Kielcach; Muzeum Geolo- } \\
\text { giczne im. Henryka Teisseyre we Wrocławiu }\end{array}$ \\
\hline Otwarte wykłady naukowe & $\begin{array}{l}\text { Muzeum Przyrody w Olsztynie; Muzeum Przyrod- } \\
\text { nicze Instytutu Systematyki i Ewolucji Zwierząt Pol- } \\
\text { skiej Akademii Nauk w Krakowie, Muzeum Ziemi } \\
\text { Polskiej Akademii Nauk w Warszawie }\end{array}$ \\
\hline $\begin{array}{l}\text { Emisja filmów przyrodniczych } \\
\text { dla różnych grup wiekowych }\end{array}$ & $\begin{array}{l}\text { Muzeum Przyrody w Olsztynie; Muzeum Ewolu- } \\
\text { cji Instytutu Paleobiologii Polskiej Akademii Nauk } \\
\text { w Warszawie }\end{array}$ \\
\hline Wystawy czasowe & $\begin{array}{l}\text { Muzeum Ewolucji Instytutu Paleobiologii Polskiej } \\
\text { Akademii Nauk w Warszawie; Muzeum Paleobota- } \\
\text { niczne Instytutu Botaniki Polskiej Akademii Nauk } \\
\text { w Krakowie; Uniwersyteckie Centrum Przyrodni- } \\
\text { cze im. prof. Andrzeja Myrchy w Białymstoku }\end{array}$ \\
\hline
\end{tabular}

Źródło: opracowanie własne na podstawie informacji zawartych na stronach internetowych miejskich muzeów przyrodniczych.

są warsztaty dla rodzin z dziećmi. Takie działania są prowadzone m.in. w Muzeum Ewolucji Instytutu Paleobiologii Polskiej Akademii Nauk i Muzeum Geologicznym Państwowego Instytutu Geologicznego w Warszawie.

Dla osób indywidualnych organizowane są również konkursy przyrodnicze, emisje filmów przyrodniczych dla różnych grup wiekowych oraz otwarte wykłady naukowe (tab. 3). Te ostatnie mogą mieć charakter cykliczny lub jednorazowy, bywają skierowane do zwiedzających bądź otwarte dla wszystkich chętnych. Wykłady najczęściej odbywają się w muzeach zarządzanych przez Polską Akademię Nauk, np. w Muzeum Przyrodniczym Instytutu Systematyki i Ewolucji Zwierząt Polskiej Akademii Nauk w Krakowie. 


\subsection{Funkcja rozrywkowa miejskich muzeów przyrodniczych}

Funkcja rozrywkowa muzeów przyrodniczych w mieście jest realizowana przez uczestnictwo tych placówek w różnych imprezach, przede wszystkim ogólnopolskich. Wydarzenia te odbywają się corocznie (np. Noc Muzeów, Festiwal Nauki) lub rzadziej jednorazowo (np. okragła rocznica utworzenia muzeum lub innego ważnego wydarzenia). $\mathrm{W}$ tabeli 4 przedstawiono najbardziej znane imprezy ogólnopolskie, w których biorą udział miejskie muzea przyrodnicze, zaczynając od najpopularniejszych.

Tabela 4. Najbardziej popularne imprezy z udziałem miejskich muzeów przyrodniczych

\begin{tabular}{|l|l|}
\hline \multicolumn{1}{|c|}{ Impreza ogólnopolska } & Przykład uczestniczącego muzeum przyrodniczego \\
\hline Noc Muzeów & $\begin{array}{l}\text { Muzeum Zoologiczne Uniwersytetu Marii Curie- } \\
\text {-Skłodowskiej w Lublinie; Muzeum Przyrodnicze } \\
\text { Uniwersytetu Eódzkiego w Łodzi; Muzeum Geolo- } \\
\text { giczne Wydziału Geologii, Geofizyki i Ochrony Śro- } \\
\text { dowiska Akademii Górniczo-Hutniczej im. Stanisła- } \\
\text { wa Staszica w Krakowie }\end{array}$ \\
\hline Festiwal Nauki & $\begin{array}{l}\text { Muzeum Geologiczne im. Jana Ziomka w Łodzi; Mu- } \\
\text { zeum Geologiczne im. Stanisława Józefa Thugutta } \\
\text { w Warszawie; Muzeum Paleobotaniczne Instytutu } \\
\text { Botaniki Polskiej Akademii Nauk w Krakowie }\end{array}$ \\
\hline $\begin{array}{l}\text { Inne (np. Noc Bibliotek, Dni } \\
\text { Otwarte Funduszy Euro- } \\
\text { pejskich, Międzynarodowy } \\
\text { Dzień Ptaków) }\end{array}$ & $\begin{array}{l}\text { Muzeum Geologiczne Państwowego Instytutu Geo- } \\
\text { logicznego w Warszawie; Muzeum Geologiczne Uni- } \\
\text { wersytetu Szczecińskiego w Szczecinie; Muzeum Ło- } \\
\text { wiectwa i Jeździectwa w Warszawie }\end{array}$ \\
\hline Giełda minerałów oraz kier- \\
masz biżuterii & $\begin{array}{l}\text { Muzeum Mineralogiczne im. Kazimierza Maślankie- } \\
\text { wicza we Wrocławiu, Muzeum Bursztynu w Gdań- } \\
\text { sku; Muzeum Geologii Złóż im. Czesława Poborskie- } \\
\text { go w Gliwicach }\end{array}$ \\
\hline Piknik Naukowy & $\begin{array}{l}\text { Muzeum Geologii Złóż im. Czesława Poborskiego } \\
\text { w Gliwicach; Centrum Edukacji Przyrodniczej Uni- } \\
\text { wersytetu Jagiellońskiego w Krakowie; Pracownia } \\
\text { Muzeum Ziemi w Poznaniu }\end{array}$ \\
\hline Noc Naukowców & $\begin{array}{l}\text { Muzeum Ewolucji Instytutu Paleobiologii Polskiej } \\
\text { Akademii Nauk i Muzeum Geologiczne Państwowe- } \\
\text { go Instytutu Geologicznego w Warszawie }\end{array}$ \\
\hline $\begin{array}{l}\text { Uniwersyteckie Centrum Przyrodnicze im. prof. An- } \\
\text { drzeja Myrchy w Białymstoku; Muzeum Przyrodni- } \\
\text { cze Instytutu Systematyki i Ewolucji Zwierząt Pol- } \\
\text { skiej Akademii Nauk w Krakowie; Muzeum i Instytut } \\
\text { Zoologii Polskiej Akademii Nauk w Warszawie }\end{array}$ \\
\hline
\end{tabular}


Tabela 4 (cd.)

\begin{tabular}{|l|l|}
\hline \multicolumn{1}{|c|}{ Impreza ogólnopolska } & \multicolumn{1}{|c|}{ Przykład uczestniczącego muzeum przyrodniczego } \\
\hline \multirow{2}{*}{ Dzień Ziemi } & $\begin{array}{l}\text { Muzeum Geologii Złóż im. Czesława Poborskiego } \\
\text { w Gliwicach; Muzeum Geologiczne Uniwersytetu } \\
\text { Szczecińskiego w Szczecinie }\end{array}$ \\
\hline Imprezy dla seniorów & $\begin{array}{l}\text { Uniwersyteckie Centrum Przyrodnicze im. prof. An- } \\
\text { drzeja Myrchy w Białymstoku; Muzeum Przyrody } \\
\text { w Olsztynie }\end{array}$ \\
\hline
\end{tabular}

Źródło: opracowanie własne na podstawie informacji zawartych na stronach internetowych miejskich muzeów przyrodniczych.

W odróżnieniu od imprez, w których biorą udział muzea przyrodnicze zlokalizowane na obszarach cennych przyrodniczo lub w ich pobliżu, wydarzenia w ośrodkach miejskich odbywają się głównie w budynkach muzealnych (Kordowska, 2015). Stanowią one jedną z wielu atrakcji organizowanych w tym samym czasie i poniekąd muszą być konkurencyjne wobec ofert innych muzeów. Z powyższych powodów program i prowadzone w tym czasie wykłady, pogadanki, pokazy, warsztaty, konkursy o tematyce przyrodniczej muszą być szczególnie ciekawe.

Nowością w ofercie muzeów przyrodniczych jest organizowanie urodzin dla dzieci. Taką imprezę można urządzić w Muzeum Ewolucji Instytutu Paleobiologii Polskiej Akademii Nauk w Warszawie. Wydarzenie jest połączeniem dobrej zabawy ze zdobywaniem wiedzy. W trakcie imprezy dzieci poznają najciekawsze okazy prehistorycznych gadów. W programie są: zwiedzanie muzeum z przewodnikiem, quizy, wykopaliska oraz rysowanie tropów odkopanych dinozaurów. Przewidziana jest również przerwa na tort $\mathrm{i}$ inne słodkości. Taka impreza zorganizowana w muzeum trwa dwie godziny (Muzeum Ewolucji Instytutu Paleobiologii Polskiej Akademii Nauk, 2019). Podobną usługę oferuje Muzeum Geologiczne Państwowego Instytutu Geologicznego w Warszawie.

\section{Promocja i kreowanie pozytywnego wizerunku muzeów przyrodniczych w mieście}

Niemal wszystkie muzea przyrodnicze $w$ miastach mają własną stronę internetową. Wyjątek stanowią Dom Przyrodnika im. E. i St. Forysiów w Bielsku-Białej i Muzeum Paleobotaniczne Instytutu Botaniki Polskiej Akademii Nauk w Krakowie. Coraz większą popularnością cieszy się 
promocja muzeów w serwisach społecznościowych. Nieco ponad połowa (17) obiektów ma własne konto na Facebooku, na którym udostępniane są informacje o nadchodzących wydarzeniach. Oczywiście wiadomości takie pojawiają się również na tradycyjnych stronach internetowych, jednak funkcje serwisu Facebook umożliwiają lepszą promocję oraz dotarcie do większego grona odbiorów. Muzea przyrodnicze w miastach są reklamowane również przez instytucje naukowe, które nimi zarządzają.

\section{Podsumowanie}

Muzea przyrodnicze w miastach związane są najczęściej z prowadzącymi je placówkami naukowymi. Tym samym najwięcej jest ich w tradycyjnych ośrodkach akademickich - dominują Warszawa i Kraków. Zbiory omawianych placówek znacznie częściej nawiązują do działalności naukowej organizujących je podmiotów niż do lokalnego otoczenia przyrodniczego. Na przykład, odwiedzając muzea warszawskie, bardziej można pogłębić wiedzę o dinozaurach z pustyni Gobi niż o gatunkach zwierząt zamieszkujących dolinę Wisły.

Z przeprowadzonej kwerendy wynika, że w muzeach przyrodniczych w miastach aktywnie popularyzowana jest wiedza o przyrodzie, poprzez organizowanie lekcji muzealnych, warsztatów przyrodniczych i uczestnictwo w różnego rodzaju imprezach. Uwagę zwraca różnorodność form rozpowszechniania nauki, obejmująca nawet - w przy padku niektórych placówek - organizację przyjęć urodzinowych o tematyce zbieżnej z ekspozycją. Większość tych zajęć ma charakter stacjonarny, co pozwala w pełni wykorzystywać zbiory, jednak służy raczej rozwijaniu wiedzy ogólnej niż zbliżeniu odwiedzających do otaczającej ich przyrody.

Obecnie przed muzealnikami stawiane są trudne zadania wynikające z rosnącej popularności multimediów. Ekspozycje oraz oferta edukacyjna i rozrywkowa muszą być stale dostosowywane do potrzeb zwiedzających, aby przyciągać ich swoją atrakcyjnością. Istnieje ryzyko, że nadmiar nowych technologii, stosowanych również w muzeum, nie ułatwi ludziom kontaktu ze środowiskiem naturalnym. Zwiedzający, zamiast wykorzystać zdobyte $w$ muzeum informacje podczas spaceru w parku czy lesie, odbędą przechadzkę wirtualną - $\mathrm{w}$ domu przed komputerem.

Opisane wyżej zmiany zachodzące w polskim muzealnictwie przyrodniczym będą z pewnością obejmować coraz większą liczbę obiektów. Trudno również przewidzieć, jak bardzo będzie ulegał wzrostowi trend na zastępowanie tradycyjnych ekspozycji multimediami. Niektóre 
z wiodących europejskich muzeów przyrodniczych (m.in. Muzeum Historii Naturalnej w Kopenhadze, Londynie i Berlinie) przekształciły się już w wyspecjalizowane, interaktywne obiekty, przypominające dzisiejsze centra edukacyjne (Strager, Astrup, 2014).

\section{Bibliografia}

Abraham, A., Sommerhalder, K., Abel, T. (2010). Landscape and well-being: a scoping study on the health-promoting impact of outdoor environments. International journal of public health, 55 (1), 59-69.

Balmford, A., Beresford, J., Green, J., Naidoo, R., Walpole, M., Manica, A. (2009). A global perspective on trends in nature-based tourism. PLOS Biology, 7 (6), 16.

Folga-Januszewska, D. (2011). 1000 muzeów w Polsce - przewodnik. Lesko: Wydawnictwo Bosz.

Główny Urząd Statystyczny (2019). Pobrane z: https://stat.gov.pl/metainformacje/slownik-pojec/pojecia-stosowane-w-statystyce-publicznej/216,pojecie.html (17.11.2019).

Instytut Systematyki i Ewolucji Zwierząt Polskiej Akademii Nauk (2019). Pobrane z: http:// isez.pan.wkraj.plrc (10.10.2019).

Jędrysiak, T. (2009). Turystyka muzealna. W: K. Buczkowska, A. Mikos von Rohrscheidt (red.), Wspótczesne formy turystyki kulturowej. T. 1 (s. 36-58). Poznań: Wydawnictwo Akademii Wychowania Fizycznego w Poznaniu.

Kąsinowska, R. (1998). Zamek w Kórniku. Kórnik: Prasowe Zakłady Graficzne.

Kluss, M., Kruczek, J. (2010). Zamek w Pszczynie - perła ślaskiej architektury. Olszanica: Wydawnictwo Bosz.

Kodeks Etyki ICOM dla Muzeów (2018). Pobrane z: https://icom.museum/wp-content/ uploads/2018/07/poland.pdf (17.11.2019).

Kordowska, M. (2015). Współczesne muzea przyrodnicze w Polsce i ich działalność. Turystyka Kulturowa, 4, 24-40.

Lijewski, T., Mikułowski, B., Wyrzykowski, J. (2008). Geografia turystyczna Polski. Warszawa: Polskie Wydawnictwa Ekonomiczne.

Ministerstwo Kultury i Dziedzictwa Narodowego (2019). Pobrane z: www.mkidn.gov. pl (7.11.2019).

Muzeum Ewolucji Instytutu Paleobiologii Polskiej Akademii Nauk (2019). Pobrane z: www.muzewol.pan.pl (11.10.2019).

Muzeum Gdańska (2019). Pobrane z: https://muzeumgdansk.pl (15.11.2019).

Muzeum Nauk o Ziemi Uniwersytetu Śląskiego (2019). Pobrane z: http://muzeum.wnoz. us.edu.pl (10.10.2019).

Muzeum Przyrodnicze Uniwersytetu Łódzkiego (2019). Pobrane z: http://web.biol.uni. lodz.pl/muzeum/ (11.10.2019).

Muzeum Przyrodnicze Uniwersytetu Wrocławskiego (2019). Pobrane z: www.muzeum-przyrodnicze.uni.wroc.pl (10.10.2019).

Narodowy Instytutu Muzealnictwa i Ochrony Zbiorów (2019). Pobrane z: www.nimoz. pl (7.11.2019).

Soga, M., Gaston, K.J. (2016). Extinction of experience: The loss of human-nature interactions. Frontiers in Ecology and the Environment, 14 (2), 94-101. 
Stasiak, A. (2000). Muzeum jako produkt turystyczny. W: A. Szwichtenberg, E. Dziegieć (red.), Przemyst turystyczny (s. 165-182). Koszalin: Wydawnictwo Uczelniane Politechniki Koszalińskiej.

Stasiak, A. (2006). Muzea wobec wyzwań współczesnej turystyki. W: A. Toczewski (red.), Rola muzeów w turystyce i krajoznawstwie (s. 29-44). Zielona Góra: Wydawnictwo Muzeum Ziemi Lubuskiej

Stasiak, A. (2007). O potrzebie rewolucji w polskim muzealnictwie XXI wieku. W: A. Stasiak (red.), Kultura i turystyka - razem czy oddzielnie? (s. 126-127). Łódź: Wydawnictwo Wyższej Szkoły Turystyki i Hotelarstwa w Łodzi.

Stasiak, A., Włodarczyk, B. (2013). Miejsca spotkań kultury i turystyki. W: B. Krakowiak, A. Stasiak, B. Włodarczyk (red.), Kultura i turystyka-miejsca spotkań (s. 29-46). Łódź: Regionalna Organizacja Turystyczna Województwa Łódzkiego.

Stefanik, M., Kamel, M. (2013). Muzea i wystawy interaktywne w Polsce - współczesna atrakcja turystyczna. Turystyka Kulturowa, 8, 5-23.

Strager, H., Astrup, J. (2014). A place for kids? The public image of natural history museums. The Museum Journal, 57 (3), 315-327.

United Nations (2018). World urbanization prospects: The 2018 Revision. Key facts. Pobrane z: https://population.un.org/wup/Publications/Files/WUP2018-KeyFacts.pdf (17.11.2019)

\title{
NATURA DLA MIESZCZUCHA - ROLA MIEJSKICH MUZEÓW PRZYRODNICZYCH W POPULARYZACJI I EDUKACJI PRZYRODNICZEJ
}

\begin{abstract}
Abstrakt: Celem artykułu jest charakterystyka polskich muzeów przyrodniczych znajdujących się w miastach, a w szczególności odpowiedź na pytanie, czy i w jaki sposób placówki te przyczyniają się do zachowania bądź odbudowania powiązań między człowiekiem a środowiskiem przyrodniczym. Zidentyfikowane muzea przyrodnicze w miastach są związane najczęściej z funkcjonującymi tam placówkami naukowymi, a ich zbiory bardziej nawiązują do profilu prowadzonych w tych jednostkach prac badawczych niż do lokalnego otoczenia przyrodniczego. $Z$ tego powodu muzea przyrodnicze $\mathrm{w}$ miastach zapewniają raczej dostęp do wiedzy ogólnej o środowisku naturalnym, a nie zbliżenie się odwiedzających do przyrody.
\end{abstract}

Słowa kluczowe: muzeum przyrodnicze, edukacja przyrodnicza, krajoznawstwo, miasto.

\section{NATURE FOR A CITY DWELLER: THE ROLE OF NATURAL HISTORY MUSEUMS IN POPULARIZING ENVIRONMENTAL EDUCATION}

\begin{abstract}
The purpose of the article is to present Polish natural history museums in cities, and answer the question whether and how these establishments contribute to preserving or restoring the bond between humans and the natural environment. The natural history museums described in the article are usually connected with academic centres in the cities and this informs their research rather than being related to the local natural environment. Thus, natural history museums offer visitors access to general knowledge about the environment rather than enabling them to experience nature more closely.
\end{abstract}

Keywords: natural science museum, environmental education, cultural heritage tourism, city. 